\title{
In retrospect chosen by Euan Nisbet
}

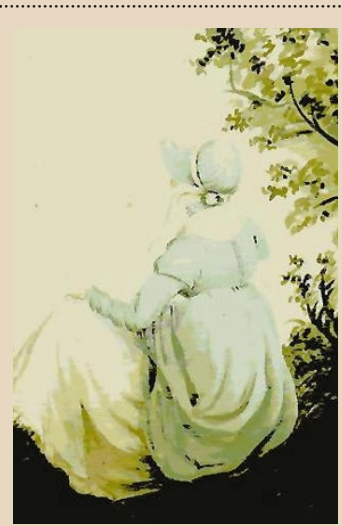

Emma

by Jane Austen

(1816)

The Climate

of London

by Luke Howard

(1833)

Austen: acute

observer of

the weather

Why choose Emma? Emma is weather.

Meteorology shapes the novel. This is a work of science, seamlessly woven into art. Emma is perfect. The slightest change would disrupt the book. How did Jane Austen create a work without flaw? Literati will have their explanations and doubtless many learned theses. But, to this illiterate from the numerati, the science perfects the art.

Emma herself is in full bloom, lovely, ready for marriage, as the spring of life passes to high summer. Day by day, the plot twists with the weather report. Is it bright? All is cheerful. Is it drizzling? Misery abounds. Or, beware, is it hot and sultry? Romance and danger loom. No doubt there is a learned tome on this somewhere, but it is a fascinating game to read Emma alongside one of the founding texts of meteorology, Luke Howard's The Climate of London.

Emma is set not far from London, near Cobham in Surrey, perhaps at Painshill, where the eccentric Mr Hamilton, related by marriage to Admiral Nelson's Emma, had created an experimental garden-farm, a ruined 'abbey' and artistic 'mill'. There was "a sweet view, sweet to the eye and the mind". The gardens are now modernized by electricity pylons so obtrusive that the observer may be permitted to suspect the hand of a planner.

Howard, a chemist and close friend of John Dalton, named the clouds: stratus, cumulus, cirrus, nimbus. He helped to lead the Bible

reconciling this with a scientific world view"; "mathematical knowledge is inherently derivative, depending entirely on our knowledge of physics"; "Plato was a very competent philosopher who believed in telling ennobling lies to the public"; "Let us start by imagining some parallel universes stacked like a pack of cards, with the pack as a whole representing the multiverse".

Even wider horizons are explored in the concluding chapter. Deutsch suggests that his four strands together provide an explanation of reality. The fourth strand is knowledge, "which seems a parochial concept until we consider it from a multiverse perspective". Regarding ourselves as pri-
Society and the fight against slavery. After the devastation of the Napoleonic wars, Howard and his friends in the United Kingdom and United States collected a vast sum, equal to many millions today — and took it to help the distressed people of Germany. Even Goethe, who wrote In Honour of Howard, addressed him as 'master'.

On the warm evening of 22 July 1813 , Howard records his visit to Alton, Hampshire. As he travelled through Chawton, just before Alton, he would have passed before Austen's dining room window, the outlook of one who was his equal in meticulous observation. Whether they met that day we do not know but it seems possible. Howard was a campaigning celebrity with links to the Lloyd and Barclay families, Quaker bankers. There were Barclays in Alton, and Austen's brother was a banker. After this time, Austen's letters seem full of weather.

Austen wrote Emma in 1814-15. It is nice to imagine that the crux of the book, the trip to Box Hill, dates from summer 1814. The lesser details may have been filled in as she wrote. Suppose then that the book records the weather of summer 1814 and winter 1814-15, day by day as she wrote, although the calendar may be 1813-14, when she began the plotting. With these assumptions, the course of the book fits beautifully with the weather recorded in The Climate of London. If so, the story may begin on 25 September, pass through autumn to snow at Christmas (now a rare event, but it did occur at Christmas 1814), then to a post-Christmas period between frost and thaw $\left(32-41^{\circ} \mathrm{F}\right.$ in Howard's record), and the late winter weather of early 1815 .

The crisis in the book occurs just before midsummer's day. Austen makes the fascinating observation of an "orchard in blossom", her famous 'error'. What are apple trees doing in flower in mid-June? But is this error — or clue? The weather was unusual in 1814 . The annual mean temperature was one of the coldest in Howard's record, and in May and June the means were colder than 1816, the 'year without a summer' after the eruption of the Tambora

marily knowledge-creating beings, we would welcome an unlimited supply of energy and hence the availability of an enormous number of computational steps. How can this be achieved?

Here Deutsch makes contact with Frank Tipler's "omega-point" theory. The omegapoint is supposed to be the end-point of the gravitational collapses after many cycles. The many-cycle concept does not seem as far-fetched as I once feared. Just before the end-point is reached, the energy generated may well be such that "an infinite number of memory accesses" and an unlimited memory capacity are feasible. So we can then march forward into what future is left volcano in what is now Indonesia. In the cool spring of 1996, mild in comparison to 1814, apple trees flowered as late as early June.

Perhaps Austen herself saw apple blossom on two hot days, 14 June $\left(85^{\circ} \mathrm{F}\right)$ and 15 June $\left(78^{\circ} \mathrm{F}\right)$, at Painshill and Box Hill. Then the weather broke. On 21-23 June, Howard notes that a "fire in the grate has been again acceptable", an observation worthy of Mr Woodhouse himself. Only as June ended did summer reappear. In July came clouds of uncommon beauty. In Emma "it cleared; the wind changed into a softer quarter; the clouds were carried off, the sun appeared; it was summer again”. Did Mr Knightley come to call on Wednesday 6 July 1814 ?

Is it presumptuous to attempt to match the weather to the novel? Possibly — an author has the right of imagination. But Austen is accurate. If she says the orchard was in bloom, then it surely was in bloom. Her meteorological sense is acute, accurately recording the passage of fronts. The perfection of the book comes from the quality of the observation; the science makes the art. Each graduate student should be set to read an Austen novel before starting a thesis.

Austen painted in miniature on two inches of ivory, but she wrote on large issues. In 1772, Judge Mansfield's far-reaching judgment ended slavery in England, helping to create modern individual liberty; in Mansfield Park the rich, cultured society can save itself only if it is cleansed of its Caribbean evil. The Prince Regent, to his credit, greatly liked that book. He would have seen the point. We should not forget it today. Sanditon, her last work, has a black subsidiary heroine: was Austen going to tackle racism?

In her tiny theatre, Austen took on the greatest of themes. Is it too much to see in her masterpiece, Emma, an allegory on Nature herself? Perhaps this is imagining too far - or may it be allowable in this journal? But it is a good excuse to follow her commendation and pour a glass of Constantia in her honour this July. Euan Nisbet is in the Department of Geology, Royal Holloway College, University of London, Egham, Surrey TW20 0EX, UK.

for us. It is a huge extrapolation! I am worried about the impression it creates among sensible nonscientists. There is more to life than the creation of knowledge, as also pointed out by Deutsch (somewhat belatedly) in his exposition.

This is a highly stimulating book, full of ideas and spurring us on to greater efforts of imagination; indeed, it lifts the veil that separates science and science fiction. Some of the arguments are hard to follow and some seem quite unconvincing. But they are always striking.

Peter T. Landsberg is in the Department of Mathematics, University of Southampton, Southampton SO17 1NP, UK. 